\title{
Business Ethics, Social Responsibility and Competitive Advantage: The Saudi Case
}

\author{
Jalawi M. Alharbi \\ General Directorate of Civil Defense \\ Qassim, Saudi Arabia \\ Samar M. Alharbi \\ College of Business and Economics \\ Qassim University, Saudi Arabia
}

\begin{abstract}
This study aims at investigating the impact of business ethics and social responsibility on competitive advantage for industrial Saudi listed companies. A survey was designed and distributed for chief executive officers at Saudi industrial listed companies to collect data about ethics, social responsibility practices and the achieved competitive advantage. The study population included all industrial companies listed on TADAWUL in 2018, The total number of the study population is 71 companies, while the sample consisted of 65 valid surveys. The results revealed that ethical practices including independency and objectivity, trust, integrity and transparency significantly affect the achievement of a competitive advantage. At the meanwhile, corporate social responsibility peroxide by environmental responsibility, customer responsibility and community responsibility, significantly affect competitive advantage. The study recommends both companies and regulators to adopt, monitor and enhance ethical and social responsible practices as drivers for better competitive advantage, and to have more focus on these practices at strategic and operational levels.
\end{abstract}

Keywords: Business Ethics, Social Responsibility, Competitive Advantage.

\section{Introduction}

The ethical aspects of ethical behavior and the need to work with business ethics are not related to specific societies. They have become a vital and important issue facing business organizations in developed and developing countries. The concept of ethics is linked to many organizational issues including financial resources, human resources, management, employees, work, leadership and executives as it guides and promotes good behavior. Business ethics are related to the behavior of individuals throughout their different operations including the way they deal with colleagues, customers and any other persons interacting with the company. Business Ethic is a key to success because it reflects the organization's confidence in its employees and people, as well as the confidence of the community it serves. Compliance with ethics will lead to employee development and reflects the interest of these employees in adhering to the professional codes of ethics, which requires management commitment towards this important success factor York (2009).

At the meanwhile, social responsibility is also another important strategic practice that is adopted by organizations seeking sustainability and growth. Different organizations implement and execute social responsibility through various activities, where some of these organizations apply social responsibility forced by law which could be noticed in developed countries, while other organizations adopt social responsibility practices in a voluntary manner, which is the case of many companies in developing countries Haider \& Lahore (2018). Currently, the topic of social responsibility is a subject of great interest in developing countries where social responsibility practices are still at earlier stage of implementation. Recent global challenges, including globalization, have increased the interest of organizations in their organizational culture and human resources and have become more responsive to business ethics and social responsibilities, which force these organizations to carry out ethical and socially responsibility actions towards working individuals and others in their external environment in order to meet the expectations of its community as ethical and social responsive organizations (Chell et al. 2016).

Considering that companies mainly aim at generating profit and achieving growth, it's important to highlight the impact of ethical social behavior on profit generating activities. Different studies worked to identify the relation between financial performance in one hand and ethical and social responsibility practices on the other hand such as Setó-Pamies \& Papaoikonomou (2016) who highlighted the importance of both business ethics and social responsibility practices in the sustainability for sustainability and growth. Also, Chuang \& Huang (2018) argued that business competitiveness is a function of ethical social responsibility and thus social responsibility is a crucial factor for enhancing company's performance. 
The current study considers the same issue but through including company's competitive advantage as a performance measure instead of including financial performance measures. In other word, the current study utilizes competitive advantage as a dependent variable in order to capture the effect of ethics and social responsibility on organizational performance and to determine how both ethics and social responsibility affect companies in one of the largest economies at the middle east namely Saudi Arabia. In which, this study aims to answer the following questions:

- Do business ethics impact organization's competitive advantage?

- Do corporate social responsibility impacts organization's competitive advantage?

\section{Literature Review}

Organizations have begun to seek more rapid and influential systems not only for globalization but for the impact of economic growth on the social and natural environment in where they operate. Organizations are working longer and longer and seek to benefit from economic progress to improve the quality of work in their organizations by restructuring harmony and compatibility between economic rationality and ethical standards in businesses especially in the world of globalization. Business Ethics is concerned with the fundamental consideration of the meaning and purpose of human existence and the ethical principles upon which economic activities depend. Current financial and economic scandals such as Helot-Barkerd, Enron, WorldCom \& Tayco have played a vital role for pushing to towards an increase of interest in business ethics and social responsibility. Researchers and practitioners are interested in how individuals make ethical decisions in the practice of their businesses, and how organizations may influence its people to be more sensitive and ethical to ethical issues.

DeVen (2008) aims to develop an ethical framework for marketing corporate social responsibility following the assumption that companies which have strong reputation must use their social responsibility initiatives to achieve its marketing objectives and other direct goals through enhancing its values and competitive advantages. Ethics consists of a set of rules and principles that determine what is the right behavior, and therefore business ethics are set of standards and principles that govern managerial behavior, which identify what is right or wrong, and they represent guidelines for decision makers. Valentine (2012) argued that business organizations should include ethics and ethical behavior as an important topic when planning the training sessions for its employees. This argument was based on the results of Valentine (2007) who asserted the need for ethics and ethical behavior to balance the efforts organizations put in its daily operations and strategic planning, which supports the results of George \& Kaler (2003) who concluded the need for ethics as a part of any business plan.

Thus, the ethical aspects and the necessity of business ethics by business organizations are not related to specific societies, but have become a vital issue for business organizations in developed and developing countries. The concept of ethics has been linked to many issues, organizational tasks, resources and human resources such as management and managers. It guides and promotes good behavior, which transfer this concept to become an important one for organizations as it represent the role for distinguishing between right and wrong in a person's behavior Daft (2003).

Modern organizations focus on objectives, principles, values and ethics in assessing the performance of employees, who are now the best resource of the organization and represent intellectual capital. They are focused and built spiritually and intellectually by providing them with knowledge, skills, abilities and behavior within the culture of the organization. In which the attitude of organizations and managers toward the ethics of work has become through the individual behavior and behavior of the organization, and this requires them to keep pace with the change that takes place in the external environment. Haider \& Lahore (2018) asserted that business ethics and social responsibility are crucial factors in achieving business competitive advantage. They introduce an approach to investigate wither companies lacking ethics and social responsibility practices could sustain its competitive advantage or not, and found that both ethics and social responsibility are important factors in sustaining the competitiveness of companies in both developing and developed countries.

Valentine \& Barnett(2007) mentioned that institutional ethics improve the rational thinking to focus on adhering to ethical issues employees through their work to ensure their ability in dealing with ethical problems. The current business environment has imposed many challenges prompted organizations to invest in activities that are consistent with law and ethical values, so that organizations work to avoid ethical conflicts (Mohr et al. 2001). Daft (2003) articulates that ethics that are related to internal values are part of the cultural of the organization, since the ethical issue affects the actions of the individual, group or organization in both negative or positive ways (Weihrich \& Koontz, 2003). In his study, Chang (2011) investigated the effect of adopting good business ethics on competitive advantage in Taiwan. His results revealed that business ethics has both direct and indirect positive effect on competitive advantage. His study is considered as one of the pioneered studies that investigated the impact of business ethics on different performance drivers such as competitive advantage. 
These results support York (2009) who argued that business ethics could be formed in a well-designed framework that could systematically lead to better competitive advantage due to the fact that business ethics is an important factor in governing any organization and thus is controlling the behavior of its employees.

At the meanwhile, current organizations deal with its communities and environment as part of its operation due to the fact that organizations should be an active player in developing its societies. This concept has been formed lately through what we call now social responsibility, which take place in different ways in modern organizations. Various definitions deal with the concept of social responsibility in terms of its principles and contents that may includeits physical and human capacities, the environment surrounding them, and the regulations and legislations that govern and regulate their work.

There is still some conceptual confusion in defining the precise meaning of social responsibility, as some still view this concept as synonymous with philanthropy, but the concept ofsocial responsibility goes beyond the limits of philanthropic work to broader and deeper meanings for economic and social development. Principles that urge attention to employment, society and the surrounding environment, and the interests of society by taking into account the impact of its activities on consumers, employees, shareholders, communities and the environment in all aspects of its operations. Asongu (2007) argues that social responsibility is the commitment of the owners towards economic activities that contribute to sustainable development through working with the community, in order to improve the standards of living in a way that serves the economy and serves the development of societies surrounding the organization in a way that contributes to increasing the welfare of society and its interests (Ameri, and Ghalibi, 2005). Social responsibility is the company's activities that maximize the long-term impact of its benefits, and could include different dimensions of the business sectors fall under legal, economic, moral and charitable responsibilities (Belal Uddin, et al., 2008). The concept of social responsibility is based on participation in economic activities of a sustainable nature that go beyond the legal requirements that protect the well-being of employees, the community as a whole and the environment, and strategically create tangible material benefits for the organization and emphasizing the elements of environmental and human sustainability. Environmental sustainability includes the use of scientific ideas that work to reduce the harmful environmental impacts of the organization's operations, such as decreasing resources and non-renewable energy and handling waste from manufacturing and consumption processes. Human sustainability is based on creating a healthy and fair working environment for employees, developing their abilities and skills and adding benefit to stakeholders from customers, suppliers and other community members (Heslin \& Ochoa, 2008).

At the same time of seeking ethical behavior and social responsible initiatives, companies still looking for its profits and financial performance. This performance could be a function for different variables such as competitive advantage. The concept of competitive advantage captured attention and important place in both strategic management and business economics Betlis (2000). Competitive advantage is an important strategic element that provides organizations with substantial and real opportunity to achieve sustained profitability compared to its competitors as competitiveness is the source that reinforces the company's economic profits and its advantage over its competitors in the areas of production, price and cost effectiveness.

Covin(2000) suggests that competitive advantage is a specific characteristic or set of characteristics that the Organization possesses and distinguishes from other organizations, so that it has a strong position vis-à-vis the various parties. The real challenge for any organization is not to produce or deliver products, but to be able to continuously satisfy the changing needs and desires of customers. The role of customers has grown and it is difficult to impose products on it. Therefore, finding competitive advantages in the products offered by the organization will result in customer satisfaction, increased loyalty, and thus the ability to sustain the organizational successes in the market.

Competitive advantage has been defined as the ability of the organization to formulate and implement strategies that make it in a better competitive position compared to similar organizations and operate in the same activity (Mustapha, 1996). Liu (2003) pointed that competitive advantage that helps a company to achieve better competitive position. Macmillan \& Mahan (2001) argued that competitive advantage is a characteristic or a set of characteristics or an element of superiority for the organization uniqueness that enables it to sustain its growing and financial sustainability through establishing new ways that are more effective than those used by competitors. Stevenson (2007) mentioned that the competitive advantage is intended to meet the needs of customers through implementing new ways that are more effective than those implemented by competitors.

In their recent study, Chuang \& Huang (2018) argued that business ethical social responsibility will impact business competitiveness. Using data from 1000 manufacturing companies in Taiwan, they found that business competitiveness is a function of ethical social responsibility. Jay \& Janet (2002) argue that competitive advantage could include having the following dimensions that could differentiate an organization from its competitors: 
1. Cost reduction: The ability of the organization to design, manufacture and market products at the lowest possible cost compared with its competitors

2. Creativity and innovation: The ability of an organization to develop, adopt and implement new ways and techniques in its daily and strategic operations in order to differentiate its services and products from others.

\section{Methodology}

\subsection{Hypothesis development}

In order to achieve the study objectives, and according to the surveyed literature, the following hypotheses were developed to be tested:

HO1: There is a statistically significant effect for business ethics on competitive advantage.

$\mathrm{HO}$ 2: There is a statistically significant effect for social responsibility on competitive advantage.

\subsection{Research Model}

\section{In Dependent variables Dependent variables}

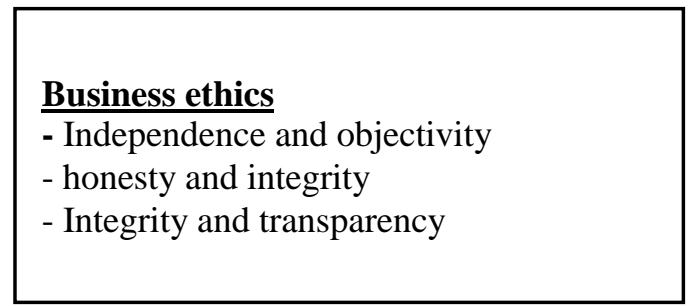

\section{Social Responsibility}

- Responsibility towards the environment

- Responsibility towards consumers

- Responsibility towards thecommunity

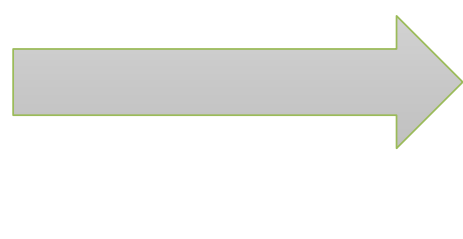

\section{Competitive advantage}

- Cost reduction

- Innovation and innovation

\section{Figure (1): Research model}

\subsection{Procedural definitions}

Business ethics: How the management company manages its relations with employees, customers, suppliers, competitors. This variable is to be measured using three main components of business ethics which are:

- Independence and objectivity

- Honesty and integrity

- Transparency

Social Responsibility: represents how a company deals with its stakeholders and how their interests are respected throughout company's different decisions and initiatives. Social responsibility dimensions adopted in the current study are:

- Environmental Responsibility.

- Consumers Responsibility.

- Community Responsibility.

Competitive advantage: is the source that enhances the company's position in the market and identify its abilities compared to competitors. Competitive advantage includes two proxies which are Cost reduction and Innovation and creativity.

\subsection{Study Population, Sample and Questionnaire}

The study population included all industrial companies listed on TADAUWL (Saudi Market Authority) which are 71 companies. Those companies were identified based on TADWUL database as of 2018. A questionnaire was designed to capture the need data about business ethics, social responsibility and competitive advantage at Saudi industrial companies. The questionnaire was distributed to CEOs at those companies. A total number of 65 questionnaires was revealed as vailed questionnaires for analysis. The questionnaire constructed of 4 parts, in which the first part includes general questions that aim at collecting information about respondents. 
The second part of the questionnaire includes questions that aim at gathering information about ethical behavior and practices, while the third part was designed to collect information about social responsibility practices and how companies adopt these practices. Finally, the fourth part aims at gathering data about competitive advantage of the companies included in the sample. The questionnaire implement Likert scale (1-5) to rank the answers of the closed ended questions that are implemented in the last three sections of the questionnaire, in which 1 indicates strongly disagree and 5 indicates strongly agree.

\section{Statistical Analysis}

\subsection{Descriptive Statistics}

This section presents the descriptive statistics of the variables included in the current study. Table 1 presents statistics that are related to business ethics and shows that COEs at Saudi listed industrial companies claim that their companies implement business ethics in its operations as the mean for the three variables measuring business ethics are more than the median value (3). Such answers indicate that business ethics are important and are implemented by the senior management.

Table 1: Descriptive Statistics of Business Ethics

\begin{tabular}{|l|l|l|}
\hline Variable & Mean & Standard Deviation \\
\hline Independence and objectivity & 4.21 & 0.78 \\
\hline Honesty and integrity & 3.86 & 0.97 \\
\hline Transparency & 4.07 & 0.88 \\
\hline
\end{tabular}

Table 2 represents descriptive statistics for the second variable which is social responsibility considering that social responsibility includes environmental, consumer and community responsibilities. The values of both the mean and the standard deviation for the three components of social responsibility indicate that Saudi listed industrial companies adopt and implement social responsible practices through its operations. These results show that social responsibility is a common practice in the sampled companies and that top management consider social responsibility as a priority throughout its decisions.

Table 2: Descriptive Statistics of Social Responsibility

\begin{tabular}{|l|l|l|}
\hline Variable & Mean & Standard Deviation \\
\hline Environment Responsibility & 4.105 & 0.962 \\
\hline Consumers Responsibility & 4.152 & 0.825 \\
\hline Community Responsibility & 4.010 & 0901 \\
\hline
\end{tabular}

Table 3 represents descriptive statistics for competitive advantage which represent the dependent variable of the current study. Competitive advantage is measured using two proxies which are cost reduction and innovation and creativity, as these two proxies are widely cited in the literature. CEOs at Saudi industrial companies tend to have positive attitude towards competitive advantage for their companies and indicate that their companies consider both cost reduction techniques and innovative procedures to enhance competitive advantage. For both proxies, the value of the mean was higher than the median value (3) with low values for the standard deviation.

Table 3: Descriptive Statistics of Competitive Advantage

\begin{tabular}{|l|l|l|}
\hline Variable & Mean & Standard Deviation \\
\hline Cost Reduction & 4.067 & 0.815 \\
\hline Innovation and Creativity & 4.030 & 0.837 \\
\hline
\end{tabular}

\subsection{Hypotheses Testing}

In order to test the study hypotheses and answer the study question, the current study implement a multiple regression model to investigate wither both business ethics and social responsibility affect competitive advantage or not.

The tested regression model utilized for the current study is as following:

$$
C A=\propto+\beta 1 B E+\beta 2 S R+e
$$

Where:

CA: Competitive Advantage.

BE: Business Ethics.

SR: Social Responsibility.

E: Error. 
The regression model hypothesizes that both business ethics and social responsibility could affect competitive advantage for Saudi industrial companies. Table 4 presents the statistics of the regression model.

Table 4: Results of Regression Model

\begin{tabular}{|l|l|l|l|l|l|}
\hline \multirow{2}{*}{ Variable } & \multicolumn{2}{|l|}{$\begin{array}{l}\text { Unstandardized } \\
\text { Coefficients }\end{array}$} & $\begin{array}{l}\text { Standardized } \\
\text { Coefficients }\end{array}$ & \multirow{2}{*}{ F } & \multirow{2}{*}{ Sig. } \\
\cline { 2 - 7 } & B & Std. Error & Beta & & \\
\hline Constant & -0.069 & 0.096 & & -0.719 & 0.473 \\
\hline Business ethics & 0.942 & 0.023 & 0.897 & 17.025 & 0.000 \\
\hline Social responsibility & 0.919 & 0.026 & 0.8720 & 14.482 & 0.000 \\
\hline
\end{tabular}

- $\mathrm{R}=0.897 \mathrm{R}^{2}=0.805$.

- Dependent Variable: Competitive Advantage.

- Predictors: Business Ethics and Social Responsibility.

The $\mathrm{R}$ value of the model is 0.897 , while the $\mathrm{R}^{2}$ value is 0.805 , which indicate that the independent variables (predictors) can explain majority of the changes of the dependent variable which is competitive advantage. This indicate that both business ethics and social responsibility are crucial variables that affect competitive advantages.

Following the regression statistics, its clearly shown that business ethics significantly and positively affect competitive advantage, where $\mathrm{F}$ value is 17.025 and significant at 0.000 level. This result supports the results of the descriptive statistics and $\mathrm{R}$ value. Following this results, it could be said that the first hypothesis is accepted, and that there is a significant positive impact for business ethics on company's competitive advantage.

On the other hand, the results of the regression test show that social responsibility significantly and positively affect competitive advantage, where $\mathrm{F}$ value is 14.482 and significant at 0.000 level. This result supports the results of the descriptive statistics and $\mathrm{R}$ value. Following this results, it could be said that the second hypothesis is accepted, and that there is a significant positive impact for social responsibility on company's competitive advantage.

\section{Results and Recommendations}

The results of the current study show the presence of a statistically significant effect for business ethics on achieve competitive advantage measured by reducing cost and innovation and creativity in Saudi industrial companies. The results showed that the companies implement business ethics is keen to avoid any relationships that may seem to harm the independency, integrity and transparency of the company. The focus on business ethics is due to its importance in managing people and thus managing different operations, which lead to better relations with customers and then for company's competitive advantage. Moreover, the results indicate the existence of a statistically positive and significant effect for social responsibility on competitive advantage measured by cost reduction and innovation and creativity in the Saudi industrial companies. The results show that the companies tend to maintain socially responsible practices toward the surrounding environment as well as both consumers and community as part of its daily and strategic operations.

As the current study utilized a questionnaire to collect the needed data about business ethics, social responsibility and competitive advantage, it could be said that it was not an easy task to design such a questionnaire due to the lack of a comprehensive framework for these variables in Saudi Arabia. This gap could be a significant reason for not having good practices in other companies, as most of Saudi companies are implementing ethical and social responsibility practices in a voluntary manner. The current study recommends Saudi regulators to work for developing a comprehensive framework for both business ethics and social responsibility in Saudi Arabia, so that all listed and maybe non listed companies can adopt. This will enhance the ability of these companies in adopting such important practices and then to enhance its competitive advantages. At the same time, the study recommends all companies to adopt ethical and socially responsible practices as a part of its daily and strategic operation due to the fact that such practices will help these companies in enhancing its competitive advantages and thus in achieving better financial performance.

\section{References}

Asongu, J. J. (2007). Innovation as an argument for corporate social responsibility. Journal of business and Public Policy, 1(3), 1-21.

Betlis, RA \& Hitt, MA. (2000). The New Competitive Land Scape. Strategic Management Journal, 16, 7-19.

Chang, C. H. (2011). The influence of corporate environmental ethics on competitive advantage: The mediation role of green innovation. Journal of Business Ethics, 104(3), 361-370. 
Chell, E., Spence, L. J., Perrini, F., \& Harris, J. D. (2016). Social entrepreneurship and business ethics: Does social equal ethical?. Journal of business ethics, 133(4), 619-625.

Chuang, S. P., \& Huang, S. J. (2018). The effect of environmental corporate social responsibility on environmental performance and business competitiveness: The mediation of green information technology capital. Journal of Business Ethics, 150(4), 991-1009.

Covin, J. G., Slevin, D. P., \& Heeley, M. B. (2000). Pioneers and followers: Competitive tactics, environment, and firm growth. Journal of business venturing, 15(2), 175-210.

Daft, Richard,L., (2003). Management, $4^{\text {th }}$ ed. Dryden Press, Orlando, USA

Van de Ven, B. (2008). An ethical framework for the marketing of corporate social responsibility. Journal of business ethics, 82(2), 339-352.

George D. , \& Kaler John. , ( 2003 ).Introduction to business ethics. First edition, publisher Chapman \& Hall.

Ghalibi, T. M., \& Ameri, S. M. (2005). Social Responsibility and Business Ethics. Business and Community. Dar Wael for publication, Jordan.

Haider, S. H., \& Lahore, A. (2018). CORPORATE SOCIAL RESPONSIBILITY, BUSINESS ETHICS, AND LABOR LAWS: A QUALITATIVE STUDY ON SMES IN SIALKOT. Journal of Legal, Ethical and Regulatory Issues, 21(3).

Heizer, J. H., \& Render, B. (2001). Operations management $.4{ }^{\text {rd }}$ ed , Prentice Hall : New Jersey , USA.

Heslin, A. Peter. and Ochoa, D. Jenna. (2008). Understanding and developing strategic corporate social responsibility, Organizational Dynamics, 37(2), 125-144.

Liu. Tsai-Lung. (2003). " Organization Learning and Social Network Market Orientation: The Role of Resource-Based View Strategy in Gaining Dynamic, Capabilities Advantage " available at. www. hicbusiness.org.

Macmillan. H. \& Mahan. T. (2001). Strategic Management, Oxford University Published, USA.

Mohr, Lois A , Webb , Deborah J , and Harris, Katherine E. (2001). Do consumers expect companies to be socially responsible? The impact of corporate social responsibility on buying behavior ", The Journal of Consumer Affairs, 35(1), 45.

Setó-Pamies, D., \& Papaoikonomou, E. (2016). A multi-level perspective for the integration of ethics, corporate social responsibility and sustainability (ECSRS) in management education. Journal of Business Ethics, 136(3), 523538.

Stevenson, W. J. (2007). Production/operations management. Burr Ridge, IL.: Irwin. $8^{\text {th }}$ ed, Von Hoffmann Press.

Uddin, M. B., Tarique, K. M., \& Hassan, M. (2008). Three dimensional aspects of corporate social responsibility.

Valentine, Sean. (2007). Perceived organizational ethics and the ethical decisions of sales and marketing personnel. Journal of Personal Selling, xxix(4), 373-388.

Valentine, Sean. (2012). Ethics training, ethical context, and sales and marketing professionals satisfaction with supervisor and coworkers. Journal of Personal Selling, 2(3),227-242 .

York, J. G. (2009). Pragmatic sustainability: Translating environmental ethics into competitive advantage. Journal of Business Ethics, 85(1), 97-109. 